\title{
THE EFFECT OF SERVICE QUALITY, PERCEIVED VALUE AND MEDIATING EFFECT OF BRAND IMAGE ON BRAND TRUST
}

\author{
Awalludin Fajar Brata Wijaya1*, Surachman Surachman ${ }^{2}$, Mugiono Mugiono ${ }^{3}$ \\ 1,2.3 Master Program in Management, Faculty of Economics and Business, Brawijaya University \\ Jl. M.T. Haryono No. 165, Malang 65145, Indonesia \\ * Corresponding Author; Email: 1awfajar11@gmail.com
}

\begin{abstract}
This study aimed to determine the effect of service quality on perceived value mediated by brand image and brand trust on the participant National Health Insurance Office Malang branch. This study was using purposive sampling. 170 people who registered as social security administration's health Malang branch were selected as the respondents. All variables are measured by Likert scale. The Data was analyzed using partial least squares. The results are service quality influences significant ability to trust and brand image, and perceived value does not significantly influence trust, but significant influences brand image. Brand image partially mediates the effect of service quality on trust and fully mediates the effect of perceived value on trust. The implication of this research is social security administration health Malang branch must maintain and improve the quality of its services, promote and socialize to improve its brand image and brand trust.
\end{abstract}

Keywords: Service quality; perceived value; brand image; trust; social security administration.

\section{Introduction}

BPJS Kesehatan is an institution that transformed from PT Askes (Persero) (National Health Insurance), the which then this company is dissolved without liquidation. The product of the BPJS Kesehatan is health insurance managed by the principle of social insurance (Kementerian Keuangan Republik Indonesia, 2004). The product from BPJS Kesehatan is health insurance that called JKN KIS (Jaminan Kesehatan Nasional Kartu Indonesia Sehat or National Health Insurance Healthy Indonesia Card). The developing economy in the community is the discrimination of health services by health facilities in collaboration with the social security administration in healthy of participants who seek treatment at the health facility for various reasons. Though it should be following the clauses of the cooperation agreement with the social security administration in health. The health facilities are required to provide health services by the provisions without any discrimination in any form (Kementerian Kesehatan Republik Indonesia, 2013). The problem that arises is the BPJS Kesehatan faces many experience various challenges related to the national health insurance program, especially the existence of discrimination in health services against health insurance of participants in Malang City, Indonesia with various motives that will affect the level of public trust in the BPJS Kesehatan in the future at Malang's branch office.

Brand trust is the desire of customers to rely on a brand with the risks faced due to the expectation of the brand that will lead to positive results (Lau \& Lee,
1999; Schurr \& Ozanne, 1985). Brand trust is an important element formed from a marketing process and an important element in making purchasing decisions.

Service quality is the expected level of excellence and control over reviews These advantages to meet customer desires (Tjiptono, 2007). The quality of service provided to customers will have a broad impact on various aspects of the company. In terms of providing services, social security administration in health makes every effort to provide the best service facing its customers, the which flows through one of its values items, namely excellent service. According to Arafah (2004), in achieving goals oriented to customer satisfaction, company performance determined consumers' perceptions of the services provided. Research of service quality on brand trust were studied by Han, Nguyen, and Lee (2015), Azizan and Mohamed (2013), Harris and Goode (2004), and Sahin, Zehir and Kitapç1 (2011) who examined the relationship of service quality to brand trust showing significant results between the two, while Chinomona, Mahlangu and Pooe (2013) suggested that service quality did not affect brand trust.

The perception of the service quality continue in the process of forming an image on the company. The company certainly hopes that by providing good service, it would be followed by an increase on the company's brand image so that reviews these consumers are able provide a positive response to it and later will attract potential customers to be able to try or buy the company's products. Research conducted by Nyadzayo and Khajehzadeh (2016) and Heri (2017) showed a significant relationship between service quality and brand image. 
Kotler (2009) stated that customer value was the difference between total customer value and total customer cost where the total customer value was a set of benefits expected by customers from a particular product or service and total customer costs were a set of costs expected by consumers spent to evaluate, obtain, use and discard the product or service. Customer perceived value are able to affect a company's brand image and trust in the product. So the higher product percieved value is the higher the brand image and the level of trust or trust in a product, and vice versa. In several studies conducted by Kayaman and Arasli (2007), Heri (2017) and Alhaddad (2015) showed that perceived value had a positive and significant effect on brand image.

Perceived value is related to brand trust, and this is consumers' perceptions of a product are able to build a strong trust in the brand of a product. Researches on the perceived value of the trust were conducted by Harris and Goode. (2004), Hasan, Kong, and Ainuddin (2014), Oktora and Achyar (2014), and Cai, Zao, and He (2015) yielding the conclusion that the perceived value had a significant effect towards brand trust. In contrast, the research conducted by Roca, José García, and José de la Vega (2009) suggested that the perceived value had no significant effect on brand trust.

Tjiptono (2005) suggested that brand image or brand description items, namely a description of the association and consumer confidence in the certain brands. Brand image are able to create trust in a product. Brand trust is the hope for reliability and good intentions of the brand (Munuera-Alemán, DelgadoBallester., \& Yaguie-Gullen, 2003). Researches conducted by Mohamed and Daud (2012), Chiang and Jang (2007), Alhaddad (2015), and Maliyah (2015) concluded that brand image had a significant effect on brand trust.

Based on this phenomenon, this research tries to fill the research gap between service quality and perceived value of brand trust by previous researchers and to determine the role of brand image as a mediator of service quality and perceived value of a brand image. Based on some of the phenomena and the problems mentioned above, the significance of the relationship variables, the significance of mediation, it has research gaps to answer that researchers choose the title of the influence of service quality and the perceived value of the brand trust through brand image (research in the BPJS Kesehatan Malang branch office).

Therefore, this study will explore the impact on service quality, perceived image, brand image on brand trust using direct and indirect effects in BPJS Kesehatan Malang branch. The result of this study will be useful for social security administration to a make right decision about how to develop brand trust.

\section{Social Insurance}

Commercial insurance is a private insurance company, the membership followed by transactional agreement among customer and company. The programs that are served depending on the needs and abilities of the insured specified in the agreement. In the field of health insurance, one is able follow a program that costs will be charged or reimbursed by the company. The amount of coverage at the option of the insured and the insured premium paid every month or every year. To Become a member of the insured person must meet Certain requirements (Darmawi, 2000).

Social insurance is an insurance that managed by the government or other agency or body designated by the government as an insurance manager (Kementerian Kesehatan Republik Indonesia, 2013). Social insurance is a mechanism to collect contributions from of participants is mandatory, in order to provide protection to the of participants on the socio-economic risks that may befall them or members of reviews their families (Kementerian Keuangan Republik Indonesia, 2004). Unlike commercial insurance, social insurance covers only basic protection the which is usually specified in legislation (Darmawi, 2000).

\section{Service Quality}

Quality is a dynamic condition that affects products, services, people, processes and environments that meet or exceed expectations (Tjiptono, 2014). In order that the definition of services quality is able be interpreted as an effort to meet the needs and desires of consumers and the accuracy of Reviews their delivery in balancing consumer expectations (Tjiptono, 2014). The services quality is able be known by comparing consumers' perceptions of the service that they actually receive/ get with the service they actually expect/want for the service attributes of a company. If the service received or perceived (perceived service) is as expected, the service quality is perceived to be good and satisfying, if the service received exceeds consumer expectations, then the service quality is perceived to be very good and quality.

According to Kotler and Armstrong (2012), definition of service is any action or activity that are able be offered by one party to another, the which is essentially intangible and does not result in any ownership. Production may be linked or not linked to a physical product. Service is the behavior of producers in order to meet consumer needs and desires in order to achieve customer satisfaction in itself. Kotler also said that the behavior is able occur during, before and after the transaction occurred. In general, a high level of service that will generate high satisfaction and repeat purchase more often. 
From the definitions of service quality, it could be able to conclude that service quality is all forms of activities Carried out by the company in order to meet consumer expectations. Services in this case are defined as services provided by the service owner in the form of ease, accessibility, speed, relationships, abilities, and hospitality aimed at attitudes and properties in providing services for customer satisfaction. Service quality are able be known by comparing consumers' perceptions of the service that they actually receive/get with the service they actually expect/want for the service attributes of a company. The relationship between producers and consumers extends far beyond the time of purchase to after-sales service, lasting forever beyond the period of product ownership.

Quality is a dynamic condition that affects the products, services, people, processes, and environments that meet or exceed expectations (Tjiptono, 2014). Furthermore, the quality of service is able be interpreted as an effort to fulfill the needs and desires of consumers and delivery accuracy in balancing consumer expectations (Tjiptono, 2007). Service quality is a focused evaluation that Reflects the customer's perception of elements of service such as interaction quality, physical environment quality, and outcome quality. Reviews These elements are in turn evaluated based on specific service quality dimensions; reliability, assurance, responsiveness, empathy and tangibles (Sahin et al., 2011).

Parasuraman et al. (1988) in Azizan and Mohamed (2013) had offered significant advances to the understanding and measurement of service quality in five aspects, tangibility, reliability, responsiveness, assurance, and empathy. Tjiptono (2011) suggested that the ten dimensions of service quality that existed before are able be summarized in five key dimensions' items, namely direct evidence, reliability, responsiveness, assurance, empathy.

The indicators of service quality (Sahin et al., 2011) are follows:

1. Facilities and public service infrastructure in the social security administration of health Malang branch well maintained.

2. Ability social security administration of health Malang branch in meeting the needs of participants.

3. Ability social security administration of health Malang branch in dealing with complaints of participants.

4. Compliance social security administration of health Malang branch employees in providing services to the of participants in accordance with standard operating procedures that have been established

5. Understand the needs of the of participants and provide effective communication of the of participants.

\section{Perceived Value}

Perceived value has various meanings raised by Several experts. Customer value or customer perceived value items, namely perceptual preference and customer evaluation of product attributes, performance attributes, and the consequences obtained from the use of products that Facilitate the achievement of goals and objectives in usage situations (Tjiptono, 2014). Tjiptono (2014) stated that customer value was the difference between the total value added obtained by consumers compared to the total costs incurred. According to Gale (1994) in Palilati (2007) customer value is the consumer's perception of the value of the quality offered relatively higher than competitors will affect the level of customer loyalty, the higher the perceived value perceived by the customer, the greater the likelihood of a relationship (transaction). The desired relationship is a long-term relationship, because the business and costs incurred by the company are believed to be far greater if they have to attract new customers or customers who have left the company, rather than maintaining it. Thus, the perceived value is able be defined as the difference between the value of the benefits of an item or service obtained by the customer and the value of the benefit that is expected by the customer.

Customer value or perceived value and customer preferences that perceptual evaluation of the performance attributes of the product attributes and the consequences derived from the use of products that facilitate the achievement of goals and objectives in usage situations (Tjiptono, 2014). Customers choose between products that offer more value, the which is the sum of product benefits, both tangible and intangible, and costs (Kotler \& Keller, 2012). Cai et al. (2015) describe that perception may be shaped by the person concerned eventually kin who will have almost the same perception that gives the perception. Higher perceived value will lead to repurchasing intention towards the services and products offered the roommates develops customer loyalty in the long run (Hasan et al., 2014).

According to Sweeney and Soutar (2001) in Tjiptono (2014), the dimensions of perceived value consisted of the following four aspects play:

1. Emotional value, which is a utility that comes from feeling or affective/positive emotions arising from consuming the product.

2. Social value, the utility gained from the ability of products to enhance the self-concept of social customer.

3. Functional value, the usefulness which comes from the quality of the product or product performance.

4. Price/value of money, the utility gained from the perception of quality and performance expected for the product. 
The indicators of perceived value (Hasan et al., 2014) are follows:

1. Price: dues social security administration of health affordable to the public.

2. The benefits: more of the benefits than drawbacks.

3. Sacrifice: providing a memorable experience of enjoying a similar product with the money and time spent.

\section{Brand Image}

Kotler and Keller (2012) defined brand image as the perceptions and beliefs held by consumers, as reflected in the associations held in consumer memory. This are able be interpreted as perceptions and trust held by consumers, which are reflected or embedded in the minds and memory of a consumer himself. This perception is able be formed from information or past experience of consumers towards the brand. While Aaker (2011) said that brand image was a collection of associations that are formed and attached to the minds of consumers. Brand image formed in the minds of consumers. Consumers who are accustomed to using the certain brands growing niche to have consistency with the brand image.

From various reviews from experts it is able be concluded that brand image is a representation of the overall perception of the brand and is formed from information and past experience of the brand. The image of a brand is related to attitudes in the form of beliefs and preferences towards a brand. Aaker (2011) stated that the brand image was a set of associations formed and attached to the consumer's mind. Brand image was formed in the minds of consumers. Aaker (2010) suggested the brand image was able be measured from four things: recognition, reputation, affinity, domain. Kotler and Keller (2012) defined brand image as the perceptions and beliefs held by consumers, as reflected in the associations held in consumer memory.

According to Keller (2013) the factors that shape the brand image were:

1. Excellence brand association

2. The Power of brands association

3. Uniqueness brand association

The indicators of brand image (Alhaddad, 2015) are follows:

1. Total quality management, the social security administration of health Malang branch a good reputation in providing services.

2. Contribution, health product guarantees social security administration program of health Malang branch for poor people.
3. Social values, social awareness.

4. Product trust, quality health insurance offered reliable.

5. Competitive price, product prices more competitive.

\section{Brand Trust}

Alif dan Harahap (2013) defined trust as a gesture showing the likes and stick to use a product or brand. Trust will arise from the minds of consumers when the products purchased are able to provide the benefit or value that consumers want in a product.

Consumer confidence according to Mowen and Minor (2002) was all the knowledge possessed by consumers and all consumers about the conclusions made objects, attributes, and benefits. Companies that have a good reputation that the advertisements tend to be trusted by the audience, people are more likely to accept the company's brand, as well as the company's logo are also more easily recognizable, and in turn consumers become more loyal (Herbig, Milewics, \& Golen, 1994).

From some sense it is able to conclude that customer confidence is a belief that arises on consumers caused by various factors that influence his judgment, customer trust itself are able be either positive or negative to a product or company.

Cai et al. (2015) described brand trust reflected consumers' beliefs about a brand's reliability, safety, and honesty. Furthermore, brand trust was a key determinant of brand loyalty, both attitudinal loyalty and purchase loyalty. Trust as a multidimensional construct in the research of business to business (B to $\mathrm{B}$ ) or business to consumer (B to $\mathrm{C}$ ), with two dimensions: honesty/reliability/expectancy and fairness/benevolence (Oktora \& Achyar, 2014). Jasfar (2009) stated that the confidence indicator consisted of three components items, namely: integrity, benevolence, competence.

The indicators of brand trust (Hasan et al., 2014) are as follows:

1. Trust in use, the confidence of participants to use health insurance products such as JKN KIS from the social security administration of health Malang branch in health facilities.

2. Attention for quality, attention to product quality health insurance products offered such as JKN KIS.

3. Attention for service, attention to the services provided at the branch office.

4. Product integrity, the quality of the health insurance products sold such as JKN KIS are trustworthy. 


\section{Conceptual Mapping}

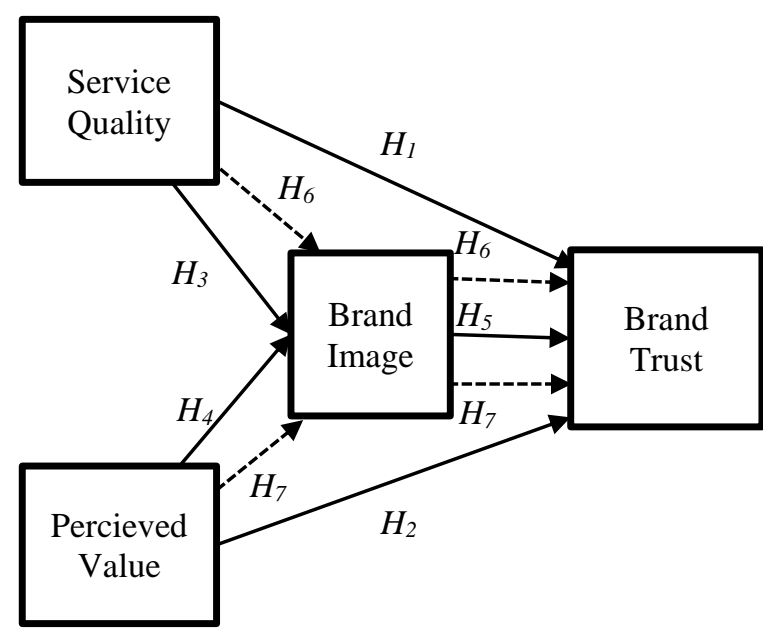

Figure 1. The conceptual research framework

\section{Relations Service Quality on Brand Trust}

Trust (confidence) the consumers of a product/service is a very important factor, high confidence for a product/service provided by the consumer to be an indicator of comfort and perceived safety of consumers in the transaction (use/purchase). The better the quality of services provided companies then consumers will be more confidence in the company and the products are given. Moreover, the company is able to provide services with more value than expected customer (Tjiptono, 2007). Trust occurs because of the satisfaction felt by consumers will be a good quality of service received, thereby service quality or better service quality have an impact on the trust. The studies by Sahin et al. (2011), Han et al. (2015), Harris and Goode (2004), and Chinomona et al. (2013) showed that brand trust was influenced by the quality of service received by consumers. Based on the above researches, the hypothesis in this study are as follows:

$H_{l}$ : Service quality has an influence brand trust.

\section{Relations Percieved Value on Brand Trust}

If customers receive good value from a product then it are able raise confidence in the brand (Shirin \& Puth, 2011). When the perceived value of giving effects to the brand image of a product/ service, psychologically he woke confidence that the products/ services it provides satisfaction, meaning that the higher the value of perceived value also then be given a more significant impact on the trust. Researches by Harris and Goode (2004), Hasan et al. (2014), Oktora and Achyar (2014), Cai et al. (2014), and Roca et al. (2009) showed the influence of perceived value of the trust. Based on these findings, the research hypothesis proposed as follows:

$\mathrm{H}_{2}$ : Percieved value has an influence on brand trust.

\section{Relations Service Quality on the Brand Image}

Grönroos (1984) in Lertwannawit and Gulid (2011) described the research quality of service during the early 1980s concluded that service quality was closely associated with the trust and commitment that service providers promised to deliver to consumers, which have a direct impact on the image of the organization. Service quality or service quality is one thing that is very fundamental, especially in the field of services, quality of services provided shall be in accordance with customer expectations, good service quality perceived by the consumer will have a positive impact on consumer behavior in response to the image of products/services received, so the likelihood that consumers return to make a purchase or use of the products/services it was very large. Influence of Service quality or service quality to the brand image is shown in the researches of Heri (2017) and Nyadzayo and Khajehzadeh (2016). Based on these findings, the research hypothesis proposed as follows:

$\mathrm{H}_{3}$ : Service quality has an influence on brand image.

\section{Relations Percieved Value to Brand Image}

Brand image is the perception of a brand is a reflection of consumer associations in memory of the brand (Keller, 1993). The consumer's perception of the value of a product/service is very important for manufacturers, manufacturers of these perceptions will create a marketing strategy to raise the price that is acceptable to consumers based on perceptions. if the price of a brand that is cheaper than perceived value, consumers will buy products/services of the brand. Brand image will have a higher value if the perceived value is built to give satisfaction and confidence in the minds of consumers that the brand is different from the products/services like. In other words, perceived value has an influence on brand image as the results shown from researches of Kayaman and Arasli (2007), Alhaddad (2015) and Heri (2017). Based on these findings, the research hypothesis proposed as follows: $H_{4}$ : Percieved value has an influence on brand image.

\section{Relations Brand Image to Brand Trust}

Lau and Lee (1999) suggested that the characteristics of brand building brand image was relatively more important in their influence on consumer confidence in the brand. brand image which have a high value as a result of perceived value that is built up in the minds of consumers will give an assurance that the Brand is satisfactory for consumers so the confidence to buy/reuse of products/services with the brand high, meaning that the brand image has an influence on brand trust as demonstrated in studies of 
Han et al. (2015), Mohamed and Daud (2010), Alhaddad (2015). Based on these findings, the research hypothesis is proposed as follows:

$H_{5}$ : Brand image has an influence on brand trust.

\section{Relations Service Quality on Brand Trust Through Brand Image}

In general, a good service will give high satisfaction to customers, such as the results of researches by Sahin et al. (2011) and Han et al. (2015), but good service is not necessarily also provide customer satisfaction if the image of the goods/services received by consumers do not have the brand value is high in the minds of consumers, establishing a good image for a product/ service is important, as this will give positive impetus to the customer's decision to choose the products/services that the like, in other words the confidence (trust) is high for a product/service that arise because of the influence of self-image that is built into the consumer. Heri (2017) provided that service quality had an influence on the trust through brand image. Based on these findings, the research hypothesis is proposed as follows:

$H_{6}$ : Service quality has an influence on brand trust through brand image.

\section{Relations Percieved Value of the Brand Trust Through Brand Image}

As shown in the studies of Harris and Goode (2004), Hasan et al. (2014), Oktora and Achyar (2014), Cai et al. (2015), Roca et al. (2009) that perceived value gave effect to the Trust. While the research conducted by Harris and Goode (2004), Hasan et al. (2014), Oktora and Achyar (2014), Cai et al. (2015), Roca et al. (2009) showed conclusively where the brand image gave an effect to the trust. On previous researches conducted by Harris and Goode (2004) showed that the perceived value had an influence on the trust through brand image. In this research, brand image is identified as intermediate variables (mediation). Based on those findings, the research hypothesis is proposed as follows:

$H_{7}$ : Perceived value has an influence on brand trust through brand image.

\section{Operational Definition of Variables}

\section{Service Quality}

Quality of service are able be interpreted as an effort to fulfill the needs and desires of consumers and delivery accuracy in balancing the expectations of consumers (Tjiptono, 2007). Indicators used to measure the quality of service refers to the studies of
Sahin et al. (2011) and Parasuraman cited by Tjiptono (2011) as the object of research in the form of customers vote on a new product are:

a. Direct evidence (Tangibles)

b. Reliability (Reliability)

c. Responsiveness (Responsiveness)

d. Assurance (Assurance)

e. Empathy (Empathy)

\section{Percieved Value}

Customer value or customer perceived value that customer perception of the value at which the company should consider the value in developing products and services that conform to what is expected of customers (Gaffar, 2007). Measurement of perceived value in this study are:

1. Social value

2. Functional value

3. Price/value of money

\section{Brand Image}

Kotler and Keller (2012) defined brand image as the perceptions and beliefs held by consumers, as reflected in the associations held in consumer memory. This are able be interpreted as the perceptions and beliefs held by consumers, which is reflected or embedded in the minds and memories of the consumers themselves. Components brand image as measured in this study were participants National Health Insurance Services consisting of various segments of the membership.

In measuring brand image of a product, according to Alhaddad (2015) there are three important parts in measuring brand image:

1. Overall management quality

2. Institutional contributions to society

3. Quality goods/services

\section{Brand Trust}

Barnes (2003) defined that trust was the belief that someone will find what he wanted in the other person, and not what he feared. Trust involves the willingness of a person to behave in particular because of the belief that its partners will provide the satisfaction he had hoped and a hope that is generally a person that says, promises or statements of other people are able be trusted. Components of trust or confidence as measured in this study were participants of BPJS Kesehatan who have used the services of health funding in health facility in collaboration with BPJS Kesehatan.

This research refers to research by Hasan $e t$ al. (2014) for the object under study have similarities as a 
fellow financial institution, namely banks. Confidence indicators in this study based on the opinions of Mayer, Davis, and Schooman (1995), which consists of three components, namely:

1. Perception integrity (integrity)

2. Virtue (benevolence)

3. Capability (competence)

\section{Research Methods}

This study uses a pattern of explanation and using the questionnaire as th instrument to gather data. Population and sample in this study were BPJS Kesehatan of participants listed in Malang and have used the services of a health financing social security administration Health and Knew thoroughly associated rights and obligations of participants as social security administration of health Malang branch.

Sugiyono (2009) stated that the determination of the amount of the sample using the formula Roscoe, that was at least 10 times the number of observed variables or 170 indicators. The sampling technique used in this research was purposive sampling according to several criteria (Sugiyono, 2009). Total questionnaires were distributed in this study a number of 205 questionnaires and 35 questionnaires were not returned to.

This study used a questionnaire using a Likert scale with 1-5 points ranging from strongly disagree (score 1) to strongly agree (score 5). The Data analysis technique used was Partial Least Square (PLS) because it was possible to do structural equation modeling with a sample size that were able be adjusted and did not require multivariate normal assumptions. It was a powerful analysis method because it was able be applied to all the data scales. In addition to being used as confirmation of theory it was also used to build whether there was no theoretical relationship or proposition testing. It was used as structural modeling with reflective indicators that were indicators considered to be influenced or reflect latent constructs.

\section{Results and Discussion}

\section{Results}

The respondents in this research are mostly men (54.8\%), aged between 26-35 years old (55\%), married status $(70.6 \%)$, with a bachelor's degree as much as $63.5 \%$. In addition, the respondents work in the private sector $(30.6 \%)$ with a salary between 5,000,001 to $10,000,000$ Rupiah $(42.3 \%)$.

The result of convergent validity on Table 1 shows that all indicators have factor loading the which are bigger than 0.4. The value of the Average Variance Extracted (AVE) and communality value of more than 0.5 . So, all indicators are able used for further analysis.
Table 1

The Result of Convergent Validity Test

\begin{tabular}{|c|c|c|c|}
\hline Indicator & $\begin{array}{l}\text { Loading } \\
\text { Factor }\end{array}$ & AVE & Communality \\
\hline Service Quality $\left(X_{I}\right)$ & & \multirow{7}{*}{0.700} & \multirow{7}{*}{0.700} \\
\hline Tangible & 0.764 & & \\
\hline Reliable & 0.869 & & \\
\hline Responsiveness & 0.888 & & \\
\hline Assurance & 0.818 & & \\
\hline Empathy & 0.839 & & \\
\hline Perceived Value $\left(X_{2}\right)$ & & & \\
\hline Price & 0.780 & \multirow{3}{*}{0.720} & \multirow{3}{*}{0.720} \\
\hline Benefit & 0.878 & & \\
\hline Sacrifice & 0.884 & & \\
\hline Brand Image $(Z)$ & & & \multirow{8}{*}{0.596} \\
\hline Total Quality & 0.820 & \multirow{7}{*}{0.596} & \\
\hline Management & & & \\
\hline Contribution & 0.714 & & \\
\hline Social Value & 0.731 & & \\
\hline Product Trust & 0.863 & & \\
\hline Competitive Price & 0.722 & & \\
\hline Brand Trust $(Y)$ & & & \\
\hline Trust in Use & 0.813 & \multirow{4}{*}{0.706} & \multirow{4}{*}{0.706} \\
\hline Attention for Quality & 0.911 & & \\
\hline Attention for Service & 0.830 & & \\
\hline Product Integrity & 0.804 & & \\
\hline
\end{tabular}

The result of discriminant validity on Table 2 shows cross loading value is more than 0.5 . So that indicate the variable is valid.

The result of the reliability test on Table 3 shows that both Cronbach's Alpha and Composite Reliability has higher than 0.7 indicate that each variable is reliable.

Table 2

The Result of Discriminant Validity

\begin{tabular}{lcccc}
\hline $\begin{array}{c}\text { Cross } \\
\text { Loading }\end{array}$ & SQ & PV & BI & BT \\
\hline SQ1 & 0.764 & 0.508 & 0.619 & 0.635 \\
SQ2 & 0.869 & 0.518 & 0.635 & 0.713 \\
SQ3 & 0.888 & 0.480 & 0.658 & 0.699 \\
SQ4 & 0.818 & 0.467 & 0.571 & 0.575 \\
SQ5 & 0.839 & 0.569 & 0.668 & 0.676 \\
PV1 & 0.430 & 0.780 & 0.504 & 0.408 \\
PV2 & 0.542 & 0.878 & 0.645 & 0.552 \\
PV3 & 0.564 & 0.884 & 0.660 & 0.592 \\
BI1 & 0.755 & 0.578 & 0.820 & 0.692 \\
BI2 & 0.501 & 0.475 & 0.714 & 0.497 \\
BI3 & 0.539 & 0.495 & 0.731 & 0.462 \\
BI4 & 0.620 & 0.626 & 0.863 & 0.735 \\
BI5 & 0.461 & 0.580 & 0.722 & 0.581 \\
BT1 & 0.634 & 0.568 & 0.638 & 0.813 \\
BT2 & 0.733 & 0.534 & 0.736 & 0.911 \\
BT3 & 0.696 & 0.525 & 0.634 & 0.830 \\
BT4 & 0.588 & 0.450 & 0614 & 0.804 \\
\hline
\end{tabular}


The test results from the direct effect hypothesis 1 to hypothesis 5 shown in Table 4 indicate that the $H_{l}$, $H_{3}, H_{4}$, and $H_{5}$ received with the value of each $p$-value of 0.00 , the which means the value is less than 0.05 , while $\mathrm{H}_{2}$ is rejected Because the $p$-value of 0.378 the which means greater than 0.05 . Table 5 shows the results of the indirect test on $H_{6}$ and $H_{7}$ with $p$-values of 0.000 each smaller than 0.05 , so it are able be concluded that $H_{6}$ and $H_{7}$ accepted.

Table 3

The result of Cronbach's Alpha and Composite Reliability

\begin{tabular}{lcc}
\hline \multicolumn{1}{c}{ Variable } & $\begin{array}{c}\text { Cronbach's } \\
\text { Alpha }\end{array}$ & $\begin{array}{c}\text { Composite } \\
\text { Reliability }\end{array}$ \\
\hline Service Quality (SQ) & 0.892 & 0.921 \\
Perceived Value (PV) & 0.806 & 0.885 \\
Brand Image (BI) & 0.830 & 0.880 \\
Brand Trust (BT) & 0.861 & 0.906 \\
\hline
\end{tabular}

The research findings show that service quality signified ability influence brand trust. This means that the better quality of service or service quality provided by BPJS Kesehatan it will increase the level of confidence or brand trust of society to BPJS Kesehatan. The results of this study confirm some previous studies by Sahin et al. (2011), Han et al. (2015), Harris and Goode (2004), and Chinomona et al. (2013) which suggests that service quality significate ability influence brand trust.

Table 4

The results of the analysis of the Direct Impact Hypothesis Testing

\begin{tabular}{cccc}
\hline Hypothesis & $\begin{array}{c}\text { Path } \\
\text { Coefficient }\end{array}$ & $t$-statistics & $\begin{array}{c}p \text { - } \\
\text { values }\end{array}$ \\
\hline$H_{l}$ & 0.459 & 6.779 & 0.000 \\
$H_{2}$ & 0.055 & 0.882 & 0.378 \\
$H_{3}$ & 0.507 & 9.376 & 0.000 \\
$H_{4}$ & 0.409 & 6.359 & 0.000 \\
$H_{5}$ & 0.396 & 5.757 & 0.000 \\
\hline
\end{tabular}

Table 5

The Results of the Analysis of the Direct Impact Hypothesis Testing

\begin{tabular}{cccc}
\hline Hypothesis & $\begin{array}{c}\text { Path } \\
\text { Coefficient }\end{array}$ & $\begin{array}{c}t \text { - } \\
\text { statistics }\end{array}$ & $p$-values \\
\hline$H_{6}$ & 0.467 & 5.025 & 0.000 \\
$H_{7}$ & 0.116 & 4.642 & 0.000 \\
\hline
\end{tabular}

\section{Effect of Service Quality on Brand Trust}

BPJS Kesehatan Malang branch strives to provide the best services for its participants. It is able be seen from the facilities and infrastructure of the participants are quite complete and adequate, such as the availability of seats in the waiting participant, signs counter clear, queuing system integration, toilet participants are clean and online service counter.

BPJS Kesehatan Malang branch employees who served as customer service also friendly, responsive and solution-to the participants or customers. Participants of BPJS Kesehatan Malang branch of the needed information will be described in detail, and for students who have problems in the use of health financing services JKN KIS will be assisted in accordance with established procedures. In providing services to the participants of BPJS Kesehatan Malang branch standards mandatory service time for employees and the designation of the SLA (service level agreement) for the handling of customer complaints related to the service of BPJS Kesehatan Malang branch.

It is a constraint of BPJS Kesehatan Malang branch of service delivery is the cone overlapping authority with partner health facilities. Some participants often complain of health services by health facilities partners to BPJS Kesehatan Malang branch, whereas the regulation (Sekretariat Kabinet Republik Indonesia, 2018). Each party is set up with their respective authorities. However, BPJS Kesehatan Malang branch remains consistent with applicable laws and regulations. Thus, it helps keep the public received complaints related to health facilities are then mediated by the relevant health facilities.

\section{Effect of Percieved Value on Brand Trust}

These research findings indicate that the perceived value does not signifiers ability influence $b$ rand trust. This means that the higher the perceived value of society then increase public trust towards BPJS Kesehatan services. The results of this study confirm the research of Roca et al. (2009) found that perceived value had no effect on trust.

The public perception that arise from other consumer experiences affect public confidence. Initially society considers health insurance products from BPJS Kesehatan an accurate solution of the government to cope with the expensive health costs. The government's commitment to the aspects of education and health is also very high, it is reflected in the budget 2019 which the government allocates five percent of the health budget, equivalent to 123 trillion Rupiah (Kementerian Keuangan Republik Indonesia, 2019) However, in its development, there are still elements partner health providers who provide unsatisfactory health services for the community or participants of BPJS Kesehatan Malang branch, so that when any problems occur then the negative news will quickly spread and the effect on public confidence. This is quite unfortunate. 


\section{Effect of Service Quality on the Brand Image}

These research findings show that service quality signifiers ability influence the brand image. This means that the better quality of service or service quality provided by BPJS Kesehatan will increase BPJS Kesehatan Malang branch's brand image in the public eye. The results of this study confirm the research of Nyadzayo and Khajehzadeh (2016) and Heri (2017) which stated that service quality significantly influenced the brand image.

BPJS Kesehatan Malang branch seeks to provide a good quality service to the participants or customers. It is able to see from the efforts to improve the quality of services that implement standardization of services, such as smiles, greetings, and greetings, informative response friendly program, define a service level agreement (SLA) to deal with complaints of participants. On the other side, BPJS Kesehatan Malang branch always holds regular training for frontline officers and chief relationship officer. So each officer of BPJS Kesehatan Malang branch will be able to consistently provide the best services in accordance with applicable regulations. Along with the development of technology, innovation of BPJS Kesehatan Malang branch also issues online services through mobile applications that are able be downloaded JKN PlayStore and AppleStore. By with this application, participants no longer need to queue up for administrative purposes. BPJS Kesehatan Malang branch is a state institution of public service is also integrated with www.lapor. go.id website so that all forms of complaints and dissatisfaction are able soon be directly reported to include supporting evidence and its completion are able be monitored openly. Thus, BPJS Kesehatan Malang branch are able to maintain and improve the quality of service so that brand its image is able also be improved.

\section{Effect of Percieved Value to Brand Image}

These research findings indicate that the perceived value signifiers ability influence the brand image. This means that the higher the perceived value of society, it will increase people's brand image of BPJS Kesehatan Malang branch. The results of this study confirm the research of Kayaman and Arasli (2007), Heri (2017) and Alhaddad (2015) which states perceived value significate ability influence the brand image.

BPJS Kesehatan Malang branch is the only health insurance with the state as a guarantor is a fundamental factor for people to be able to trust the new health insurance product, which is a JKN KIS is a product that is sufficiently trustworthy. Dues of BPJS Kesehatan Malang branch is more affordable compared with other private insurance and guarantee programs. They are more extensive health care costs with no limit fees provided that the appropriate procedures applied will be borne entirely. The government also initiates specific program guarantees for citizens who are not able to afford. To guarantee the health is through public health insurance (Assurance) which is funded by the state through the state budget or regional health insurance. It's financed through the budget increase for weak economy people to enroll into the program of BPJS Kesehatan. The central government and the local governments themselves are always to prioritize public health guarantee by routine budget of APBN (national budget) and APBD (regional budget) to include the community in the health insurance program of JKN KIS. It makes BPJS Kesehatan to have more value in the eyes of society. Thus, the high perceived value will raise the brand image society to BPJS Kesehatan.

\section{Effect of Brand Image on Brand Trust}

These research findings indicate that a significant effect on brand image brand trust. This means that the higher the brand image of BPJS Kesehatan Malang branch will increase trust of the public. The results of this study confirm the researches of Chiang and Jang (2007), Mohamed and Daud (2010), Alhaddad (2015), and Maliyah (2015) which concluded that the brand image significate ability influence brand trust.

BPJS Kesehatan Malang branch is a body of public services continue to be consistent in providing the best service to participants that aims to maintain the trust of the public and the government in carrying out the responsibility of providing for the public health financing. Poor image development of society on health facilities provided is BPJS Kesehatan's responsibility. It is related, because as BPJS Kesehatan insurance has its own role and health facilities as health care providers also have their own role. But in reality some health facilities accidentally took the blame BPJS Kesehatan when there is a group of people who complain about their health care.

BPJS Kesehatan as financial institution also is maintaining its reputation in maintaining the trust funds from the public. Payments to BPJS Kesehatan such as dues and fines of health services through a virtual bank account through a different one every individual or institution. With the system then accountability of BPJS Kesehatan as financial institutions are well preserved because automation system will minimize the deviation. In terms of claims payment, BPJS Kesehatan implements a FIFO (first in first out). It means the claim which enters first will be paid prior to such regulation and fair system in payouts claim. This will have an impact on the reputation BPJS Kesehatan in the eyes of partner health facilities. 


\section{Effect Service Quality to Brand Trust through Brand Image}

The test results indicate that the effect of mediation on service quality brand trust by involving brand image as a mediating variable. Mediation impact of the brand image is mediating part (partial mediation). Its meaning is the absence of the brand image of the service quality are able still to affect brand trust. The results of this study confirm the results of previous studies of Heri (2017) and Han et al. (2015).

BPJS Kesehatan Malang branch is a state agency in charge of serving the general public in the field of health insurance. BPJS Kesehatan is obliged to provide a good service for the whole community that become participants. Communities that have been satisfied using the services of partner of BPJS Kesehatan Malang branch in health facilities as well as from direct service of BPJS Kesehatan itsself will judge that BPJS Kesehatan's trustworthy image which would then recommend health insurance products from BPJS Kesehatan to their colleagues.

The principle of mutual assistance in BPJS Kesehatan is a major fundamental in shaping the image of BPJS Kesehatan Malang branch as social institution. Community must be very happy if in making a purchase, the money that is issued is not just a commercial nature, but there are social values contained therein. Thus brand image is able mediate the relationship between service quality to brand trust.

\section{Effect perceived Value to Brand Trust through Brand Image}

The test results indicate that the effect of mediation on the perceived value brand trust by involving brand image as a mediating variable. Mediation impact the brand image is the full mediation (full mediation). Its meaning is the absence of the perceived value of brand image are able not affect brand trust. The results of this study confirm the results of previous researches done by Harris and Goode (2004) and Alhaddad (2015) which suggests brand image may mediate the relationship between perceived value of the brand trust.

The public has good perception of health insurance from BPJS Kesehatan since as the embodiment of the state's presence in the fulfillment of health financing needs of its people. The government is very serious in implementing the universal insurance program for all Indonesian people so that the health insurance program JKN KIS of BPJS Kesehatan always is well guarded by a related party. Undeniably also health insurance program JKN KIS of BPJS Kesehatan is also experiencing problems, especially problems of sufficient funds for the financing needs of the health of Indonesian society. However, this does not matter the participants of BPJS Kesehatan, as long as it is borne entirely by the state and throughout the country still exist it they are able be said BPJS Kesehatan and the program are not able to be bankrupt.

\section{Conclusion}

This study has implications for the development of related concepts of service quality, perceived value, brand image, and brand trust of the BPJS Kesehatan Malang branch. We hope this research are able to be references relating to the effect on service quality and perceived value to the brand image mediating role in affecting brand trust.

Empirically, this study shows that the variables of service quality has a significant impact on brand trust supported by researches of Sahin et al. (2011), Han et al. (2015), Harris and Goode (2004), Chinomona et al. (2013), and Azizan and Mohamed (2013). Variable service quality has a significant impact on the brand image that is supported by the results of researches of Nyadzayo and Khajehzadeh (2016) and Heri (2017). Brand image variable has a mediating role between the variables of service quality with brand trust. It also has a significant effect. It is supported by researches of Heri (2017) and Han et al. (2015). Thus the brand image variables are able be used as a mediation between service quality with brand trust,

Perceived value variable shows no significant relationship to the brand trust. It is contrary to researches of Harris and Goode (2004), Hasan et al. (2014), Oktora and Achyar (2014) and Cai et al. (2015) but it has the same conclusion as the study Roca et al. (2009). Perceived value has a significant ability effect on brand image. It is in line with researches of Kayaman and Arasli (2007), Heri (2017), and Alhaddad (2015). Variable perceived value shows a significant relationship to brand trust with mediating variable given brand image. This is according to researches of Harris and Goode (2004) and Alhaddad (2015). Perceived value has no direct influence on the brand trust. So the brand image indicates mediation role as a bridge linking the influence of perceived value against brand trust.

Practical contributions are able to be explained as follows: BPJS Kesehatan Malang branch has to maintain the quality of its services to participants. Along with the increasing number of participants of BPJS Kesehatan and rising health costs are borne. BPJS Kesehatan needs to deliver new innovations in the development of its services, so that the challenges ahead to maintain the trust and related services are able to overcome with good quality.

BPJS Kesehatan Malang branch needs actively to maintain the public perception of BPJS Kesehatan remains positive. Reality on the ground suggests that the perception of BPJS Kesehatan influenced by the 
health services in partner health facilities is a significate ability challenge, since each party actually has the rights and obligations of each.

BPJS Kesehatan Malang branch needs to keep always positive brand image to maintain brand trust. With a positive brand image that will strengthen the influence perceived value to trust and influence service quality to brand trust. Things to BPJS Kesehatan Malang branch are able to do direct promotion through various media such as other commercial advertising, but the content of the ad contains a message of social and moral for people to regularly pay dues BPJS Kesehatan and registering other acquaintances.

General research has addressed the formulation of the problem, but there are still many limitations, among others: There are a few samples of participants of BPJS Kesehatan which are located in Malang but are not registered BPJS Kesehatan Malang branch. So it is able not to be used as a sample.

Several samples are still less understood associated rights and obligations between partners of BPJS Kesehatan Malang branch with health facilities that need educational efforts against these samples. Some of the samples did not want to directly fill out the questionnaire but get someone else to insert it. Measurement of brand trust are able still be measured by other variables in addition to service quality and perceived value, such as the brand experience (Baser, Cintamür, \& Arslan, 2015), brand awareness (Alkhawaldeh, Al-Salaymeh, Alshare, \& Eneizan, 2017), and satisfaction (Park, Lee, Lee, \& Truex, 2012).

\section{References}

Aaker, D. (2010). Manajemen ekuitas merek. Jakarta: Spektrum Mitra Utama.

------- (2011). Brand relevance: Making competitors irrelevant. San Fransisco: Jossey Bas.

Alhaddad, A. (2015). Perceived quality, brand image and brand trust as determinants of brand loyalty. Journal of Research in Business and Management, 3(4), 1-8

Alif, G., \& Harahap, Y. (2013). Komunikasi interpersonal dan fasilitas kesehatan: Pengaruhnya terhadap kepercayaan, loyalitas dan wom rumah sakit. Journal of Business and Entrepreneurship, 1(3), 1-12.

Alkhawaldeh, A. B., Al-Salaymeh, M., Alshare, F., \& Eneizan, B. M. (2017). The effect of brand awareness on brand loyalty: Mediating role of brand commitment. European Journal of Business and Management, 9 (36), 38-47.

Arafah, W. (2004). Analisis kualitas pelayanan rumah sakit terhadap image (Studi pada rumah sakit pemerintah "X" di Jakarta Selatan). Metode Riset bisnis dan Manajemen, 4 (1), 55-75.
Azizan, N., \& Mohamed, B. (2013). The effects of perceived service quality on patient satisfaction at a public hospital in state of Pahang, Malaysia. Asian Journal of Social Sciences \& Humanities, 2 (3), 307-323.

Barnes, J. G. (2003). Secrets of customer relationship management. Yogyakarta: Andi.

Başer, İ., Cintamür, İ., \& Arslan, F. (2015). Examining the effect of brand experience on consumer satisfaction, brand trust and brand loyalty. Marmara Üniversitesi İktisadi ve İdari Bilimler Dergisi, 37(2), 101-128. https://doi.org/10.14780/iibd.51 125

Cai, Y., Zhao, G., \& He, J. (2015). Influences of two modes of intergenerational communication on brand equity. Journal of Business Research, 68 (3), 553-560. DOI: 10.1016/j.jbusr es.2014.09. 007

Chiang, C. F., \& Jang, S. C. S. (2007). The effects of perceived price and brand image on value and purchase intention: Leisure travelers' attitudes toward online hotel booking. Journal of Hospitality \& Leisure Marketing, 15(3), 49-69. https://doi. org/ 10.1300/J150v15n03_04

Chinomona, R., Mahlangu, D., \& Pooe, D. (2013). Brand service quality, satisfaction, trust and preference as predictors of consumer brand loyalty in the retailing industry. Mediterranean Journal of Social Sciences, 4(14), 181-190.

Darmawi, H. (2000). Manajemen asuransi. Jakarta: Bumi Aksara.

Gaffar, V. 2007. Customer relationship management and marketing public relation. Bandung: Alfabeta.

Han, S., Nguyen, B., \& Lee, T. (2015). Consumerbased chain restaurant brand equity, brand reputation, and brand trust. International Journal of Hospitality Management, 50, 84-93.

Harris, L., \& Goode, M. (2004). The four levels of loyalty and the pivotal role of trust: A study of online service dynamics. Journal of Retailing, 80(2), 139-158.

Hasan, H., Kong, T., \& Ainuddin, R. (2014). Effects of perceived value and trust on customer loyalty towards foreign banks in Sabah, Malaysia. Global Journal of Emerging Trends in e-Business, Marketing and Consumer Psychology, 1(2), 137-153.

Herbig, P., Milewics, J., \& Golen, J. (1994). A model of reputation building and destruction. Journal of Business Research, 31(1), 23-31. https://doi.org/ 10.1016/0148-2963(94)90042-6

Heri, H. (2017). Analysis the effect of service quality, customers value, customer satisfaction and customer trust on corporate image. IOSR Journal of Business and Management, 19(06), 38-46.

Jasfar, F. (2009). Manajemen jasa pendekatan terpadu. $1^{\text {st }}$ Ed. Jakarta: Erlangga. 
Kayaman, R., \& Arasli, H. (2007). Customer based brand equity: Evidence from the hotel industry. Managing Service Quality: An International Journal, 17(1), 92-109.

Keller, K. L. (1993). Conceptualizing, measuring, and managing customer-based brand equity. Journal of Marketing, 57(1), 1-22. DOI: 10.2307/1252 054 - (2013). Strategic brand management: Building, measuring, and managing brand equity. Fourth Edition. Harlow, Essex: Pearson Education Inc.

Kementerian Kesehatan Republik Indonesia (2013). Peraturan Menteri Kesehatan Republik Indonesia nomor 71 tahun 2013 tentang pelayanan kesehatan pada jaminan kesehatan nasional. Jakarta: Kementerian Kesehatan Republik Indonesia.

Kementerian Keuangan Republik Indonesia (2004). Undang-undang Republik Indonesia nomor 40 tahun 2004 tentang sistem jaminan sosial nasional. Jakarta: Kementerian Keuangan Republik Indonesia.

Kementerian Keuangan Republik Indonesia (2019). Anggaran pendapatan dan belanja negara tahun 2019. Jakarta: Kementerian Keuangan Republik Indonesia.

Kotler, P. (2009). Manajemen pemasaran. $13^{\text {th }}$ Ed. Jakarta: Erlangga.

Kotler, P., \& Armstrong, G. (2012). Prinsip-prinsip pemasaran. $13^{\text {th }}$ Ed. Jakarta: Erlangga.

Kotler, P., \& Keller, K. L. (2012). Manajemen pemasaran. $12^{\text {th }}$ Ed. Jakarta: Erlangga.

Lertwannawit, A., \& Gulid, N. (2011). International tourists service quality perception and behavioural loyalty toward medical tourism in Bangkok metropolitan area. The Journal of Applied Business Research, 27(6), 1-12. https://doi.org/10.19 030/jabr.v27i6.6460

Lau, G. \& Lee, S. (1999). Consumers' trust in a brand and the link to brand loyalty. Journal of MarketFocused Management, 4, 341-370.

Maliyah, S. (2015). Pengaruh citra merek, kepercayaan (trust) dan komitmen terhadap loyalitas nasabah pada PT. Henan Putihrai Asset Management. Jurnal Ilmiah Manajemen dan Bisnis, 1(1), 9-21. https://dx.doi.org/10.22441/ jimb.v1i1.559

Mayer, R. C., Davis, J. H., \& Schoorman, F. D. (1995). An integrative model of organizational trust. Academy of Management Review, 20(3), 709-734. DOI: $10.2307 / 258792$

Mohamed, R. N., \& Daud, N. M. (2012). Cultural uncertainty on brand trust of fast food industry in Malaysia. Procedia - Social and Behavioral Sciences, 42, 399-412.

Mowen, J. C., \& Minor, M. (2002). Perilaku konsumen. Jakarta: Erlangga.

Munuera-Alemán, J. L., Delgado-Ballester., E., \& Yagüe-Gullen, M. J. (2003). Development and validation of a trust scale. International Journal of
Market Research, 45(1), 35-54. https://doi.org/ $10.1177 \% 2$ F14707853030400103

Nyadzayo, M., \& Khajehzadeh, S. (2016). The antecedents of customer loyalty: A moderated mediation model of customer relationship management quality and brand image. Journal of Retailing and Consumer Services, 30, 262-270.

Oktora, K., \& Achyar, A. (2014). The effect of postpurchase perceived-value towards the relationship quality of hajj and umrah travel agencies in Indonesia. The South East Asian Journal of Management, 8(1), 29-46. https: //doi.org/10.21002/ seam.v8i1.3100.

Palilati, A. (2007). Analisis pengaruh nilai pelanggan, kepuasan terhadap loyalitas nasabah tabungan perbankan di Sulawesi Selatan. Jurnal Manajemen dan Kewirausahaan, 9(1), 73-81. https://do i.org/10.9744/j mk.9.1.pp.\%2073-81.

Park, J., Lee, J., Lee, H., \& Truex, D. (2012). Exploring the impact of communication effectiveness on service quality, trust and relationship commitment in IT services. International Journal of Information Management, 32 (5), 459-468. https:// doi.org/10.1016/j.ijinfom gt.2012.02.005.

Roca, J., José García, J., \& José de la Vega, J. (2009). The importance of perceived trust, security and privacy in online trading systems. Information Management \& Computer Security, 17(2), 96113. https://doi.org/10.1108/0968522091096 3983

Sahin, A., Zehir, C. \& Kitapçı, H. (2011). The effects of brand experiences, trust and satisfaction on buildingn brand loyalty: An emperical research on global brands.

Schurr, P. H., \& Ozanne, J. L. (1985). Influences on exchange processes: Buyers' preconceptions of a seller's trustworthiness and bargaining toughness. Journal of Consumer Research, 11(4), 939-953.

Sekretariat Kabinet Republik Indonesia (2018). Peraturan Presiden Republik Indonesia nomor 82 tahun 2018 tentang jaminan kesehatan. Jakarta: Sekretariat Kabinet Republik Indonesia.

Shirin, A., \& Puth, G. (2011). Customer satisfaction, brand trust and variety seeking as determinants of brand loyalty. Afriare able Journal of Business Management, 5(30), 11899-11915. DOI: 10.589 7/AJBM11.238

Sugiyono (2009). Metode penelitian kuantitatif kualitatif dan $r \& d$. Bandung: Alfabeta.

Tjiptono, F. (2005). Pemasaran jasa. Malang: Bayumedia. (2007). Strategi pemasaran. $2^{\text {nd }}$ Ed. Yogyakarta: Andi. - (2011). Service management mewujudkan layanan prima. $2^{\text {nd }}$ Ed. Yogyakarta: Andi. - (2014). Pemasaran jasa-prinsip, penerapan, dan penelitian. Yogyakarta: Andi Offset. 